\title{
PENGEMBANGAN BAHAN AJAR MATEMATIKA DENGAN MEMANFAATKAN GEOGEBRA UNTUK MENINGKATKAN PEMAHAMAN KONSEP
}

\author{
(DEVELOPMENT OF MATHEMATICS TEACHING MATERIAL USING \\ GEOGEBRA TO INCREASE CONCEPTUAL UNDERSTANDING)
}

\section{Indri Lestari}

STKIP Pelita Pratama, indri.math13@gmail.com

\begin{abstract}
Abstrak
Penelitian ini bertujuan untuk dapat mengetahui karakteristik buku yang memadai bagi peningkatan pemahaman konsep terhadap matematika, khususnya pada pokok bahasan fungsi dengan memanfaatkan program Geogebra. Metode penelitian yang digunakan yaitu penelitian dan pengembangan, dimana penelitian ini dimaksudkan untuk mengembangkan dan menghasilkan produk tertentu, serta menguji keefektifan produk tersebut. Subyek dalam penelitian ini adalah siswa SMP Negeri 6 Kota Serang dengan uji skala terbatas dilakukan pada 5 siswa, sedangkan uji lapangan dilakukan terhadap 15 siswa. Kesimpulan yang diperoleh dalam penelitian ini siswa yang menggunakan bahan ajar dengan memanfaatkan program Geogebra mengalami peningkatan pemahaman konsep dibandingkan dengan siswa sebelum menggunakan bahan ajar.
\end{abstract}

Kata kunci: Bahan Ajar, Geogebra, Pemahaman Konsep

\begin{abstract}
This study aims to find out the characteristics of the appropriate book for improving understanding of mathematical concepts, especially on the subject of function by utilizing Geogebra program. The research method used is research and development, where the research is intended to develop and produce certain products, and test the effectiveness of these products. Subjects in this study were students of SMP Negeri 6 in the city of Serang with a limited scale test conducted on 5 students, while field tests were conducted on 15 students. The conclusions developed in this study that use the teaching materials by utilizing Geogebra program have improved conceptual understanding compared with the students before using the teaching materials.
\end{abstract}

Keywords: conceptual understanding, Geogebra, experiment class, research and development, teaching materials

\section{PENDAHULUAN}

Kontribusi matematika begitu besar dalam kehidupan manusia dan perkembangan ilmu pengetahuan lainnya. Sehingga pelajaran matematika di sekolah dapat digunakan sebagai alat untuk memecahkan masalah dalam mata pelajaran lain atau kehidupan sehari-hari, membentuk pola pikir siswa dalam 
memahami suatu pengertian, dan dapat menunjukkan bahwa matematika itu selalu mencari kebenaran. Dalam pembelajaran matematika di sekolah biasanya siswa hanya disuruh menghafal konsep atau rumus tanpa melihat langsung masalahmasalah yang ada hubungannya dengan konsep tersebut. Selain itu strukturstruktur yang abstrak dapat menjadi salah satu faktor penyebab konsep-konsep matematika sulit untuk dipahami. Keadaan ini mengakibatkan pemahaman konsep matematika rendah siswa menjadi rendah.

Memahami suatu konsep merupakan kompetensi yang ditunjukkan siswa dalam melakukan prosedur (algoritma) secara luwes, akurat, efisien dan tepat. Adapun indikator-indikator yang menunjukkan pemahaman konsep matematika tersebut menurut Jihad dan Haris (Arvianto dkk., 2011: 172) meliputi hal-hal berikut: 1) menyatakan ulang sebuah konsep; 2) mengklasifikasikan obyek-obyek menurut sifat-sifat tertentu (sesuai dengan konsepnya); 3) memberi contoh dan non contoh dari konsep; 4) menyajikan konsep dalam berbagai bentuk representasi matematis; 5) mengembangkan syarat perlu dan syarat cukup suatu konsep menggunakan, memanfaatkan, dan memilih prosedur atau operasi tertentu. Menurut Perkins (Uno \& Umar, 2009: 172) membandingkan konsep pemahaman dengan pengetahuan. Perkins mempertahankan bahwa pemahaman menunjuk pada apa yang dapat seseorang lakukan dengan informasi itu, dari pada yang telah mereka ingat. Pengetahuan melibatkan tindakan dari pada penguasaan. Ketika para siswa mengerti sesuatu, mereka dapat menjelaskan konsep-konsep dalam kalimat mereka sendiri, menggunakan informasi dengan tepat dalam konteks baru, membuat analogi baru, dan generalisasi. Peghafalan dan pembacaan tidak menunjukkan pemahaman. Menurut Wahyudin (Dahlan, 2004: 4) dalam penelitiannya menemukan lima kelemahan yang ada pada siswa, diantaranya adalah kurang memiliki kemampuan materi prasyarat yang baik, kurang memiliki kemampuan untuk memahami serta mengenali konsep-konsep dasar matematika, kurang memiliki kemampuan dan ketelitian dalam menyimak atau mengenali sebuah persoalan matematika, kurang memiliki kemampuan menyimak kembali sebuah jawaban yang diperoleh (apakah jawaban itu mungkin / tidak), kurang memiliki kemampuan bernalar yang logis dalam menyelesaikan persoalan atau soal matematika. Ditambahkan oleh Oktaviyanthi \& Herman (2016) bahwa salah satu penyebab suatu konsep tidak tersampaikan pada peserta didik dikarenakan ketidaktepatan metode yang digunakan dalam proses penyampaian. Beberapa penyebab di atas dapat disimpulkan bahwa dasar utama siswa dalam belajar yaitu siswa dituntut untuk paham akan konsepnya terlebih dahulu. Walaupun diketahui pemahaman konsep setiap siswa pasti berbeda satu sama lainnya, hal ini dikarenakan kecepatan mereka di dalam menangkap materi pelajaran yang diberikan.

Materi yang dapat memicu pemahaman konsep salah satunya tentang fungsi. Fungsi atau pemetaan adalah relasi khusus yang memasangkan setiap anggota satu himpunan dengan tepat satu anggota satu himpunan yang lain menurut Agus (2007: 26). Disana siswa dituntut untuk dapat memahami pengertian fungsi, mencari nilai fungsi, dan menggambar pada grafik. Menurut penelitian Susanti (2014) menunjukkan bahwa kesulitan-kesulitan yang dialami siswa dalam mempelajari materi fungsi yaitu: (1) kesulitan dalam memahami konsep fungsi; (2) kesulitan dalam memahami dan menggunakan konsep prasyarat, diantaranya adalah konsep himpunan; (3) kesulitan dalam memahami 
dan menggunakan prinsip yang berkaitan dengan materi fungsi yaitu cara menyatakan fungsi, menghitung nilai fungsi, dan menyusun tabel fungsi; (4) kesulitan dalam memahami dan menggunakan prinsip yang berkaitan dengan materi prasyarat yaitu cara penulisan himpunan, menentukan anggota suatu himpunan yang dinyatakan dengan cara deskripsi dan kesulitan dalam operasi bilangan bulat; (5) kesulitan dalam menentukan prapeta dari suatu nilai fungsi dan menentukkan bentuk nilai fungsi jika nilai dan data fungsi diketahui; (6) kesulitan dalam menyelesaikan soal berbentuk verbal.

Guru sebagai faktor utama siswa paham atau tidaknya suatu materi haruslah dapat menjelaskan tidak hanya dengan menggunakan metode ceramah tetapi diperlukan metode lainnya sehingga siswa ikut aktif di dalamnya. Salah satunya yaitu penggunaan bahan ajar interaktif (Supriani \& Oktaviyanthi, 2014). Penggunaan bahan ajar interaktif terutama dalam mengintegrasikan mathematics software dapat mempermudah siswa di dalam memahami konsep (Oktaviyanthi \& Herman, 2016). Dengan cara mengintegrasikan teknologi ke dalam proses pengajaran dan pembelajaran matematika, diharapkan dapat meningkatkan kemampuan peserta didik dalam memahami ide-ide kompleks dan mampu mengonstruksi pemecahan masalah matematika (Oktaviyanthi \& Supriani, 2015). Selain itu, pembelajaran matematika berbantuan teknologi dapat membantu peserta didik untuk terlibat lebih luas menghubungkan dunia sekolah dengan dunia nyata (Oktaviyanthi, Safaah \& Agus, 2017). Salah satu teknologi dalam pembelajaran matematika yang dapat dimanfaatkan adalah program Geogebra.

Geogebra adalah software matematika dinamis yang menggabungkan geometri, aljabar, dan kalkulus (Hohenwarter, 2008). Dengan menggunakan program Geogebra ini siswa diharapkan juga dapat belajar mandiri, walaupun tanpa pengajaran formal. Di mana siswa dapat mengeksplorasi kemampuan yang dimilikinya dalam penggunaan program ini. Jadi jika sewaktu-waktu siswa ingin mengulas ulang materi tentang fungsi, siswa tersebut dapat mempelajarinya di applet Geogebra dan video tutorial yang telah tersedia di program ini tanpa harus bertanya pada guru. Beberapa pemanfaatan program Geogebra dalam pembelajaran matematika adalah sebagai berikut: 1) dapat menghasilkan lukisanlukisan geometri dengan cepat dan teliti dibandingkan dengan menggunakan pensil, penggaris, atau jangka; 2) adanya fasilitas animasi dan gerakan-gerakan manipulasi (dragging) pada program Geogebra dapat memberikan pengalaman visual yang lebih jelas kepada siswa dalam memahami konsep geometri; 3) dapat dimanfaatkan sebagai balikan/evaluasi untuk memastikan bahwa lukisan yang telah dibuat benar; 4) mempermudah guru/siswa untuk menyelidiki atau menunjukkan sifat - sifat yang berlaku pada suatu objek geometri.

Bahan ajar juga sangat dibutuhkan oleh guru untuk pendamping siswa dalam belajar. Bahan ajar adalah segala bentuk bahan yang digunakan untuk membantu guru atau instruktur dalam melaksanakan proses pembelajaran di kelas menurut National Centre for Competency Based Training (Praswoto, 2011: 16). Pandangan dari ahli lainya mengatakan bahwa bahan ajar adalah seperangkat materi yang disusun secara sistematis, baik tertulis maupun tidak tertulis, sehingga tercipta lingkungan atau susasana yang memungkinkan peserta didik untuk belajar. Bahan ajar yang dipakai yakni bahan ajar digital yang dalam hal ini berisikan materi fungsi dalam format file $p d f$. Pemakaian bahan ajar ini menggunakan bantuan komputer sehingga berbagai ilustrasi maupun simulasi 
yang ada dalam bahan ajar ini dapat berjalan maksimal sehingga tercipta interaktifitas secara langsung antara siswa dan bahan ajar.

Guru harus memilih bahan ajar yang sesuai dengan kurikulum, karakteristik sasaran, dan tuntutan pemecahan masalah belajar. Bahan ajar yang dikembangkan oleh guru pasti mengharapkan tujuan dan manfaatnya baik bagi guru itu sendiri maupun siswanya. Berikut ini penjelasan tujuan dan manfaat bahan ajar: 1) menyediakan bahan ajar yang sesuai dengan tuntutan kurikulum dengan mempertimbangkan kebutuhan peserta didik, yakni bahan ajar yang sesuai dengan karakteristik dan setting atau lingkungan sosial siswa; 2) manfaat bahan ajar bagi guru yaitu diperoleh bahan ajar yang sesuai tuntutan kurikulum dan sesuai dengan kebutuhan belajar siswa, tidak lagi tergantung kepada buku teks yang terkadang sulit diperoleh, memperkaya karena dikembangkan dengan menggunakan berbagai referensi, menambah khasanah pengetahuan dan pengalaman guru dalam menuli bahan ajar, membangun komunikasi pembelajaran yang efektif antara guru dengan guru karena siswa akan merasa lebih percaya kepada gurunya, menambah angka kredit jika dikumpulkan menjadi buku dan diterbitkan; 3) manfaatnya bagi siswa yaitu kegiatan pembelajaran menjadi lebih menarik, kesempatan untuk belajar secara mandiri dan mengurangi ketergantungan terhadap kehadiran guru, mendapatkan kemudahan dalam mempelajari setiap kompetensi yang harus dikuasainya.

Berdasarkan latar belakang tersebut, tujuan dari penelitian pengembangan ini yaitu sebagai berikut: 1) untuk mengetahui tingkat kelayakan produk bahan ajar menurut para ahli; 2) terdapatnya peningkatan pemahaman konsep siswa sebelum dan sesudah uji coba produk.

\section{KAJIAN TEORI}

\section{A. Bahan Ajar}

Bahan ajar adalah segala bentuk bahan yang digunakan untuk membantu guru atau instruktur dalam melaksanakan proses pembelajaran di kelas menurut National Centre for Competency Based Training (Praswoto, 2011: 16). Guru harus memilih bahan ajar yang sesuai dengan kurikulum, karakteristik sasaran, dan tuntutan pemecahan masalah belajar. Bahan ajar yang dikembangkan oleh guru pasti mengharapkan tujuan dan manfaatnya baik bagi guru itu sendiri maupun siswanya. Berikut ini penjelasan tujuan dan manfaat bahan ajar: 1) menyediakan bahan ajar yang sesuai dengan tuntutan kurikulum dengan mempertimbangkan kebutuhan peserta didik, yakni bahan ajar yang sesuai dengan karakteristik dan setting atau lingkungan sosial siswa; 2) manfaat bahan ajar bagi guru yaitu: a) diperoleh bahan ajar yang sesuai tuntutan kurikulum dan sesuai dengan kebutuhan belajar siswa; b) tidak lagi tergantung kepada buku teks yang terkadang sulit diperoleh; c) memperkaya karena dikembangkan dengan menggunakan berbagai referensi; d) menambah khasanah pengetahuan dan pengalaman guru dalam menuli bahan ajar; e) membangun komunikasi pembelajaran yang efektif antara guru dengan guru karena siswa akan merasa lebih percaya kepada gurunya; f) menambah angka kredit jika dikumpulkan menjadi buku dan diterbitkan. 3) bahan ajar sangat banyak manfaatnya bagi siswa yaitu: a) kegiatan pembelajaran menjadi lebih menarik; b) kesempatan untuk belajar secara mandiri dan mengurangi ketergantungan terhadap kehadiran guru; c) mendapatkan kemudahan dalam mempelajari setiap kompetensi yang harus 
dikuasainya. Selain itu, dengan adanya bahan ajar dapat membimbing alur pikir siswa dalam memahami suatu konsep dan memberikan gambaran utuh mengenai suatu materi (Oktaviyanthi \& Dahlan, 2018).

Menurut Depdiknas (Prastowo, 2011), secara garis besar teknik penyusunan bahan ajar interaktif adalah: 1) dalamnya penyusunan bahan ajar interaktif, diperlukan pengetahuan dan keterampilan pendukung yang memadai, terutama dalam mengoperasikan peralatan, seperti komputer, kamera video, dan kamera foto; 2) bahan ajar interaktif biasanya disajikan dalam bentuk compact disc; 3) menurunkan judul dari kompetensi dasar atau materi pokok sesuai dengan besar kecilnya materi; 4) menuliskan petunjuk pembelajarannya; 5) menjelaskan informasi pendukung secara jelas, padat, dan menarik dalam bentuk tertulis maupun gambar diam atau bergerak; 6) menuliskan tugas-tugas dalam program interaktif; 7) melakukan penilaian terhadap hasil karya dari tugas yang diberikan, yang pada akhir pembelajaran dapat dilihat oleh guru melalui komputer; 8) menggunakan berbagai sumber belajar yang dapat memperkaya materi, misalnya buku, majalah internet, dan jurnal hasil penelitian sebagai bahan dalam membuat program bahan ajar interaktif.

\section{B. Pemahaman Konsep}

Mempelajari matematika sangat penting untuk memahami konsep dasarnya terlebih dahulu, karena matematika merupakan ilmu tentang penelusuran pola dan hubungan. Matematika merupakan pelajaran yang terstruktur di mana antara konsep materi yang satu dengan materi lainnya saling berkaitan, sehingga pemahaman konsep awal akan berpengaruh terhadap pemahaman konsep berikutnya. Siswa akan menguasai materi dengan baik, apabila mereka paham akan konsepnya, sehingga berbagai macam variasi soal dan permasalahannya akan mudah diselesaikan. Berdasakan hal tersebut, maka pemahaman konsep dalam matematika sangat penting hal ini sesuai dengan pernyataan Sudjana (2008) bahwa tipe hasil belajar yang lebih tinggi dari pada pengetahuan adalah pemahaman.

Suherman (2008: 5) pemahaman adalah kemampuan memaknainya dengan pertanyaan mengapa, dari mana, atau bagaimana. Sedangkan indikator yang harus dimiliki siswa untuk pemahaman adalah: mengenal, mengingat, menerapkan, algoritma, menduga, mengaitkan, menghitung, memberikan contoh. Indikator tersebut tidak berdiri sendiri, melainkan terpadu dengan yang lainnya.

Depdiknas (Khakim, 2011: 19) menyatakan indikator yang menunjukan pemahaman konsep antara lain: a) menyatakan ulang sebuah konsep; b) mengklasifikasi objek-objek menurut sifat-sifat tertentu (sesuai dengan konsepnya); c) memberi contoh dan non contoh dari konsep; d) Menyajikan konsep dalam berbagai bentuk representasi matematis; e) mengembangkan syarat perlu dan syarat cukup suatu konsep; f) menggunakan, memanfaatkan, dan memilih prosedur atau operasi tertentu; g) mengaplikasikan konsep atau algoritma pemecahan masalah. Dalam penelitian ini, indikator yang akan dikembangkan setara dengan pemahaman instrumental dan pemahan relasional, yaitu: a) menyatakan ulang sebuah konsep yaitu siswa dapat menyatakan ulang sebuah konsep sesuai pemahaman yang Mereka ketahui (menggunakan kata-kata sendiri); b) mengklasifikasikan objek- objek menurut sifat- sifat tertentu sesuai dengan konsepnya yaitu siswa mampu mengelompokkan objek- objek berdasarkan sifat- 
sifat yang diketahuinya; c) menggunakan, memanfaatkan dan memilih prosedur atau operasi tertentu, yakni siswa dapat memanfaatkan salah satu prosedur atau operasi tertertentu dari beberapa prosedur yang telah diketahui dengan memilih prosedur yang dianggapnya paling mudah.

\section{Geogebra}

Berbagai manfaat program komputer dalam pembelajaran matematika dikemukakan oleh Kusumah (Mahmudi, 2011: 2). Menurutnya, program-program komputer sangat ideal untuk dimanfaatkan dalam pembelajaran konsep-konsep matematika yang menuntut ketelitian tinggi, konsep atau prinsip yang repetitif, penyelesaian grafik secara tepat, cepat, dan akurat. Salah satu program komputer yang dapat dimanfaatkan sebagai media pembelajaran matematika adalah program Geogebra. Geogebra dikembangkan oleh Markus Hohenwarter pada tahun 2001. Menurut Hohenwarter (2008: 6), Geogebra adalah software matematika dinamis yang menggabungkan geometri, aljabar, dan kalkulus.. Program ini dapat dimanfaatkan secara bebas yang dapat diunduh dari www.geogebra.org.

Menurut Hohenwarter \& Fuchs (Mahmudi, 2011: 4), Geogebra sangat bermanfaat sebagai media pembelajaran matematika dengan beragam aktivitas sebagai berikut: a) sebagai media demonstrasi dan visualisasi, yaitu dalam pembelajaran yang bersifat tradisional, guru memanfaatkan Geogebra untuk mendemonstrasikan dan memvisualisasikan konsep-konsep matematika tertentu;

b) sebagai alat bantu konstruksi, yaitu Geogebra digunakan untuk memvisualisasikan konstruksi. Menu utama Geogebra adalah: File, Edit, View, Option, Tools, Windows, dan Help untuk menggambar objek-objek geometri. Menu File digunakan untuk membuat, membuka, menyimpan, dan mengekspor file, serta keluar program. Menu Edit digunakan untuk mengedit lukisan. Menu View digunakan untuk mengatur tampilan. Menu Option untuk mengatur berbagai fitur tampilan, seperti pengaturan ukuran huruf, pengaturan jenis (style) objekobjek geometri, dan sebagainya. Sedangkan menu Help menyediakan petunjuk teknis penggunaan program Geogebra.

\section{METODE PENELITIAN}

Penelitian ini bertujuan untuk menghasilkan suatu produk yaitu sebuah bahan ajar dengan memanfaatkan program Geogebra yang dapat dimanfaatkan dalam pembelajaran, sehingga penelitian ini menggunakan rancangan penelitian pengembangan. Sugiyono (2010: 407), penelitian untuk pengembangan (Research and Development) adalah penelitan untuk mengembangkan dan menghasilkan produk tertentu, dan menguji keefektifan produk tersebut.

Tahap-tahapan penelitian yang digunakan dalam penelitian ini yaitu menggunakan modifikasi dari Borg dan Gall yang dilakukan oleh Sukmadinata (2008: 184) yaitu studi pendahuluan, pengembangan produk, dan uji produk. Dimana pada studi pendahuluan meliputi studi kepustakaan, survei lapangan, penyusunan draf awal produk, uji ahli, dan revisi.

Instrumen penelitian ini dibagi menjadi dua yaitu instrumen tes dan non tes. Teknik pengumpulan data dalam penelitian ini adalah dengan memberikan tes-awal dan tes-akhir untuk mengukur pemahaman konsep serta angket kemandirian belajar siswa yang diberikan sebelum dan sesudah diberikan produk bahan ajar dari uji skala terbatas 5 siswa SMP Negeri 6 Kota Serang dan uji skala 
lapangan 15 siswa SMP Negeri 6 Kota Serang. Indikator keberhasilan dalam penelitian ini adalah produk yang dikembangkan yaitu bahan ajar dengan memanfaatkan program Geogebra dapat terselesaikan dengan tingkat kelayakan menurut para ahli minimal 75\% menurut Ahli Multimedia, Ahli Pendidikan, dan Ahli Matematika serta adanya peningkatan pemahaman konsep dan kemandirian belajar siswa pada uji lapangan.

\section{HASIL DAN PEMBAHASAN}

\section{A. Merancang dan Membangun Bahan Ajar Berbasis Pemahaman Konsep dengan Memanfaatkan Program Geogebra}

Merancang dan membangun bahan ajar berbasis pemahaman konsep dengan bantuan Geogebra sebagai salah satu media yang dapat digunakan oleh siswa dalam pembelajaran agar siswa dapat belajar secara mandiri. Selain itu, bahan ajar juga dapat dimanfaatkan oleh guru sebagai bahan ajar dalam pembelajaran matematika khususnya materi fungsi.

Desain awal pembuatan bahan ajar berbasis pemahaman konsep dengan bantuan Geogebra adalah materi fungsi yang isinya berupa teks narasi dan disertai dengan berbagai ilustrasi dan animasi, serta video-video untuk memperjelas dalam penyampaian materi.

Gambar 1 sampai gambar 4 merupakan produk akhir bahan ajar matematika dengan memanfaaatkan program Geogebra yang terdiri dari 2 sub bahasan pada materi relasi yaitu pengertian relasi dan menyatakan relasi, kemudian 6 sub bahasan pada materi fungsi yaitu pengertian fungsi, grafik fungsi, notasi dan niali fungsi, menentukan rumus fungsi, sifat fungsi, dan macam-macam fungsi. Adapun gambaran produk akhir bahan ajar yaitu: 1) media penyimpanan: CD-R dan Kertas 80 gram; 2) ukuran: B5 (16 cm x $24 \mathrm{~cm})$; 3) ketebalan: 56 halaman (bolak balik+cover); 4) jenis huruf: Times New Roman, Algerian, Showcard Gothic, dan Snap ITC; 5) format: *PDF (Portable Document Format); 6) materi: Fungsi yang disajikan dengan menggunakan teks narasi yang berisi konflik kognitif, ilustrasi gambar, dan terdapat ilustrasi Geogebra yang dibuat mengarah kepada peningkatan pemahaman konsep dan kemandirian belajar siswa; 7) sofware kebutuhan: Adobe Reader 9 atau versi diatasnya, Java Application.

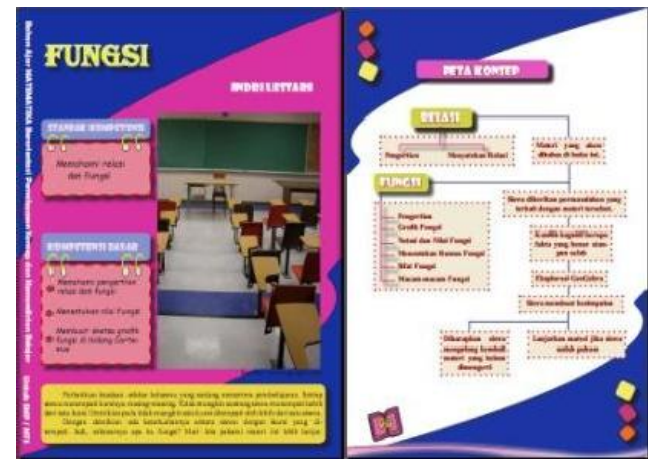

a. Peta Konsep

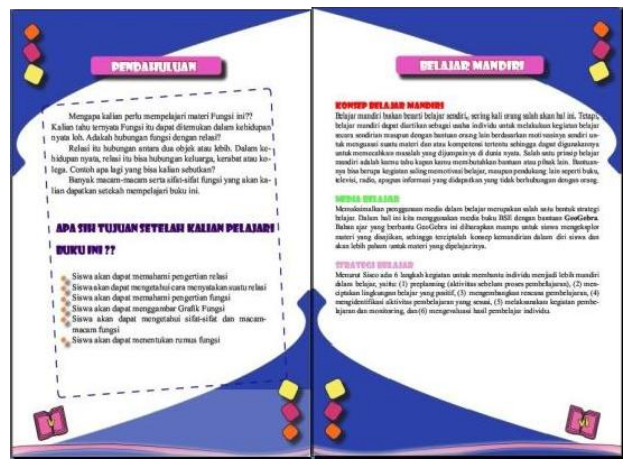

b. Pendahuluan

Gambar 1. Visuaslisasi Peta Konsep (a) dan Pendahuluan (b) pada Draf Akhir Bahan Ajar 


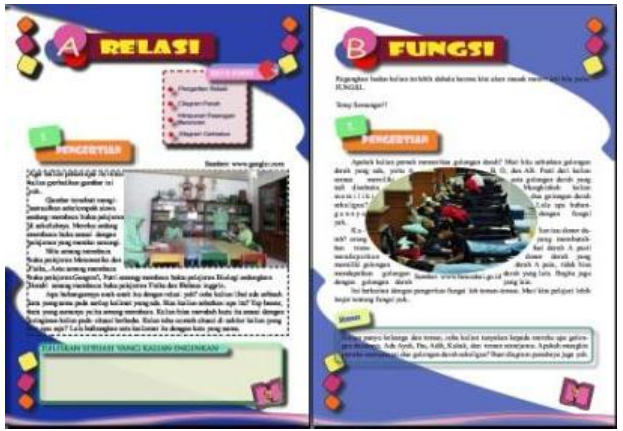

c. Materi Relasi dan Fungsi

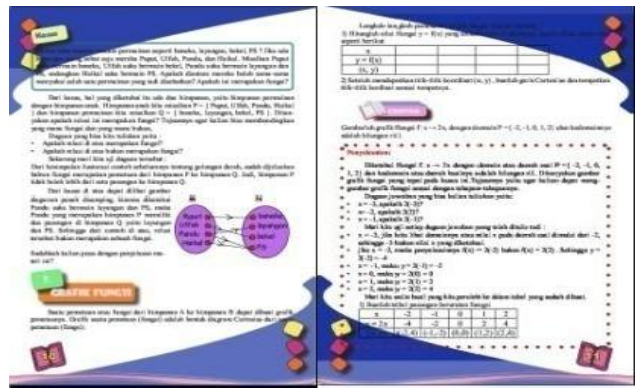

d. Sub-Pokok Grafik Fungsi

Gambar 2. Visualisasi Materi Relasi dan Fungsi (c) dan Sub-Pokok Grafik Fungsi (d) pada Draf Akhir Bahan Ajar

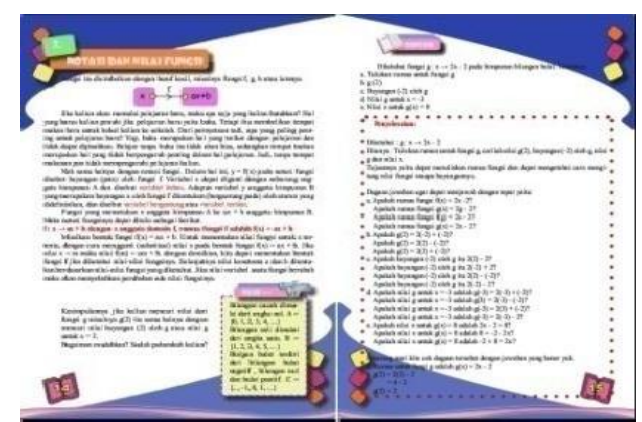

e. Sub-Pokok Notasi dan Nilai Fungsi

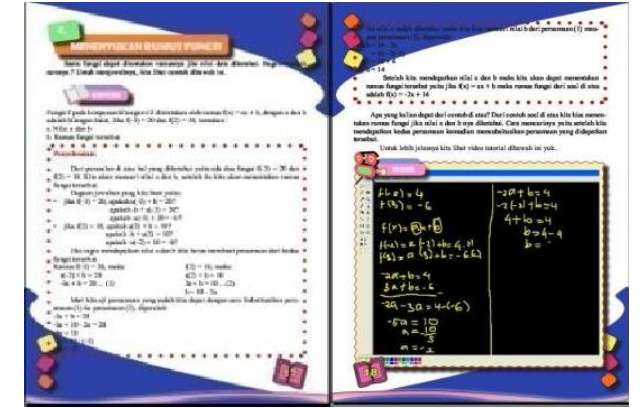

f. Sub-Pokok Menentukan Rumus Fungsi

Gambar 3. Visualisasi Sub-Pokok Notasi dan Nilai Fungsi (e) dan Menentukan Rumus Fungsi (f) pada Draf Akhir Bahan Ajar

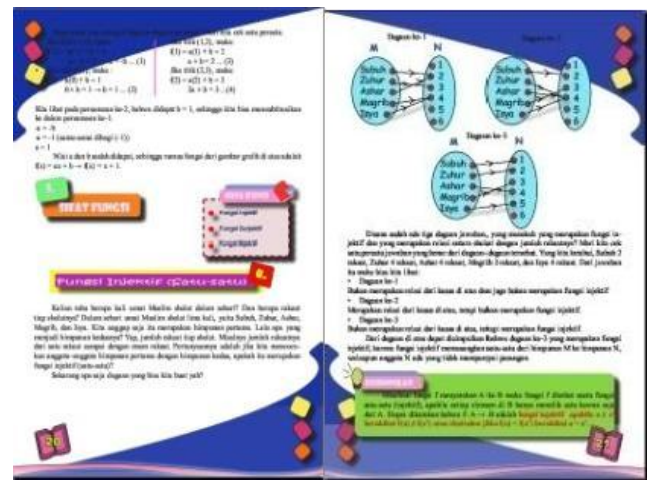

g. Sub-Pokok Sifat Fungsi

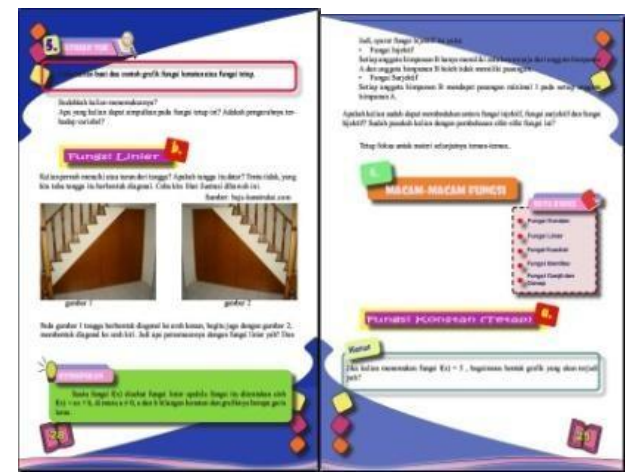

h. Sub-Pokok Macam-macam Fungsi

Gambar 4. Visuaslisasi Sub-Pokok Sifat Fungsi (g) dan Sub-Pokok Macam-macam

Fungsi (h) pada Draf Akhir Bahan Ajar

\section{B. Pemahaman Konsep Matematika Setelah Menggunakan Bahan Ajar Matematika dengan Memanfaatkan Program Geogebra}

Pada bab sebelumnya telah dilakukan bahwa analisis deskriptif dilakukan untuk memperoleh gambaran umum mengenai data tes-awal dan data tes-akhir sebelum dan setelah uji coba produk. Untuk mengetahui kemampuan awal siswa sebelum uji coba produk, maka siswa diberikan tes pemahaman konsep (tes-awal) 
yang dilakukan pada saat uji lapangan. Sedangkan untuk mengetahui kemampuan akhir siswa setelah uji coba produk, siswa kembali diberikan tes pemahaman konsep (tes-akhir) dan untuk mengetahui kualitas peningkatan kemampuan pemahaman konsep matematikanya dilakukan analisis data gain sebelum dan setelah uji coba produk.

Sebelum dilakukannya uji lapangan, pengujian produk dilakukan pada skala terbatas dimana hasil tes pemahaman konsep pada saat uji skala terbatas disajikan dalam tabel di bawah ini.

Tabel 1. Data Statistik Deskriptif Siswa Pada Uji Skala Terbatas

\begin{tabular}{ccccccccc}
\hline & \multirow{2}{*}{$\begin{array}{c}\text { Banyak } \\
\text { Siswa }\end{array}$} & Maks & Min & $\begin{array}{c}\text { Rata- } \\
\text { rata }\end{array}$ & Maks & Min & $\begin{array}{c}\text { Rata- } \\
\text { rata }\end{array}$ & Peningkatan \\
\hline $\begin{array}{c}\text { Uji } \\
\text { Lapangan }\end{array}$ & 5 & 6 & 5 & 5,8 & 9 & 7 & 7,8 & 2 \\
\hline
\end{tabular}

Berdasarkan tabel di atas, terlihat bahwa pencapaian rataan skor pemahaman siswa pada skala terbatas sebesar 5,8 untuk tes awal dan 7,8 untuk tes akhir. Sehingga terdapatnya peningkatan sebesar 2 dimana dapat disimpulkan bahwa pemahaman konsep setelah pemberian produk bahan ajar lebih baik dibandingkan $\mathrm{d}$ sebelum pemberian produk bahan ajar.

Tabel 2. Statistik Deskriptif Data Indeks Gain Pada Uji Skala Terbatas

\begin{tabular}{ccc}
\hline Aspek & Banyak Siswa & Rata-Rata Indeks Gain \\
\hline Pemahaman Konsep Siswa & 5 & 0,47 \\
\hline
\end{tabular}

Setelah uji skala terbatas dan dilakukan revisi produk dengan menambahkan jumlah latihan soal, selanjutnya dilakukan uji lapangan terhadap 15 siswa. Hasil tes pemahaman konsep pada saat uji lapangan disajikan dalam tabel di bawah ini.

Tabel 3. Data Statistik Deskriptif Siswa Pada Uji Lapangan

\begin{tabular}{ccccccccc}
\hline & $\begin{array}{c}\text { Banyak } \\
\text { Siswa }\end{array}$ & Maks & Min & $\begin{array}{c}\text { Rata- } \\
\text { rata }\end{array}$ & Maks & Min & $\begin{array}{c}\text { Rata- } \\
\text { rata }\end{array}$ & Peningkatan \\
\hline $\begin{array}{c}\text { Uji } \\
\text { Lapangan }\end{array}$ & 15 & 8 & 3 & 5,8 & 9 & 6 & 7,67 & 1,87 \\
\hline
\end{tabular}

Data statistik deskriptif tersebut dapat dapat dilihat bahwa rata-rata indeks gain pada uji skala terbatas adalah 0,47 berada pada kategori sedang.

Berdasarkan tabel di atas, terlihat bahwa pencapaian rataan skor pemahaman siswa sebesar 5,8 untuk tes awal dan 7,67 untuk tes akhir. Sehingga terdapatnya peningkatan sebesar 1,87 dimana dapat disimpulkan bahwa pemahaman konsep setelah pemberian produk bahan ajar lebih baik dibandingkan sebelum pemberian produk bahan ajar. 
Tabel 4. Statistik Deskriptif Data Indeks Gain Pada Uji Lapangan

\begin{tabular}{ccc}
\hline Aspek & Banyak Siswa & Rata-Rata Indeks Gain \\
\hline Pemahaman Konsep Siswa & 15 & 0,45
\end{tabular}

Dari statistik deskriptif tersebut, dapat dilihat bahwa rata-rata indeks gain pada uji lapangan adalah 0,45 berada pada kategori sedang.

Pembelajaran matematika dengan menggunakan bahan ajar bahan ajar dengan memanfaatkan bantuan Geogebra dapat meningkatkan kemampuan pemahaman konsep siswa lebih baik dikarenakan dalam proses pembelajarannya siswa dilibatkan secara aktif karena bahan ajar ini memuat konflik-konflik kognitif yang dapat membuat siswa lebih paham akan ilustrasi yang diberikan.

\section{SIMPULAN DAN SARAN}

Bahan ajar berbasis pemahaman konsep siswa dengan bantuan Geogebra ini dibuat melalui tahap penelitian dan pengembangan dengan tingkat kelayakan 78,8\% dari uji Ahli Multimedia, Ahli Matematika dan Ahli Pendidikan.

Pemahaman konsep sebelum dan setelah menggunakan bahan ajar terdapat peningkatan, meskipun tidak terlalu besar. Gain pada uji skala terbatas adalah 0,47 . Sedangkan pada uji lapangan gain atau rata-rata peningkatan pemahaman konsepnya adalah 0,45 .

Bagi peneliti yang akan mengembangkan sebuah bahan ajar matematika yang bersifat interaktif dan melakukan penelitian yang berkaitan dengan bahan ajar diharapkan untu membuat bahan ajar pada pokok bahasan yang lain, menambahkan game yang bersifat edukatif dan berhubungan dengan materi yang sedang dibahas untuk membantu siswa belajar dengan lebih menyenangkan sekaligus melatih siswa berpikir cepat dan tepat dan bagi para pengembang multimedia pembelajaran yang ingin melanjutkan mengembangkan bahan ajar berbasis pemahaman konsep dan kemandirian belaja pada materi bangun ruang sisi datar agar melakukan perbaikan pada bagian applet Geogebra dan lebih memunculkan lagi konflik kognitifnya.

\section{DAFTAR RUJUKAN}

Agus, N.A. (2007). Mudah Belajar Matematika 2. Jakarta: Pusat Perbukuan Departemen Pendidikan Nasional.

Ali Mahmudi. (2011). Pemanfaatan Geogebra dalam Pembelajaran Matematika. Makalah disajikan dalam Seminar Nasional LPM Universitas Negeri Yogyakarta.

Arvianto, I.R. dkk. (2011). Penggunaan Multimedia Pembelajaran untuk Meningkatkan Pemahama Konsep Siswa dan dengan pendekatan instruksional Concrete Representational Abtract (CRA). 170-179.

Dahlan, J. A. (2004). Meningkatkan Kemampuan Penalaran dan Pemahaman Matematis Siswa Sekolah Lanjutan Tingkat Pertama Melalui Pendekatan Open-Ended. Disertasi Doktor tidak diterbitkan. Bandung: Pascasarjana Universitas Pendidikan Indonesia

Hohenwarter, M., et al. (2008). Teaching and Calculus with free dynamicmathematics software Geogebra. International Congress on Mathematical Education 16: 1-9. 
Praswoto, A. (2011). Panduan Kreatif Membuat Bahan Ajar Inovatif. Yogyakarta: Pusat Diva Press.

Oktaviyanthi, R. dan Supriani, Y. (2015). Utilizing Microsoft Mathematics in Teaching and Learning Calculus. Journal on Mathematics Education, (6) 1, (Online) (http://jims-b.org/wp-content/uploads/2015/03/7-Full-IndoMSJME-61-Rina-Oktaviyanthi.pdf, diakses 13 Agustus 2016).

Oktaviyanthi, R. dan Herman, T. (2016, Oktober). A Delivery Mode Study: The Effect of Self-Paced Video Learning on First-Year College Students' Achievement in Calculus. Artikel dipresentasikan pada The $4^{\text {th }}$ International Conference on Quantitative Sciences and Its Applications, Universiti Utara Malaysia, Putrajaya, Malaysia. (Online) (http://aip.scitation.org/doi/abs/10.1063/1.4966102, diakses 13 Januari 2016).

Oktaviyanthi, R. dan Dahlan, J.A. (2018). Developing Guided Worksheet for Cognitive Apprenticeship Approach in Teaching Formal Definition of the Limit of A Function. IOP Conference Series: Materials Science and $\begin{array}{llll}\text { Engineering } & 335 & (1), & 012120 .\end{array}$ (http://iopscience.iop.org/article/10.1088/1757-899X/335/1/012120/pdf, diakses 27 April 2018).

Oktaviyanthi, R., Safaah, E., dan Agus, R. N. (2017). Pemberdayaan Keterampilan Guru Matematika dalam Menyusun Bahan Ajar Berbantuan Mathematics Education Software. Jurnal Pengabdian Masyarakat Wirakrama Parahita, (1) 1, 19-24. (Online), (http://ejurnal.lppmunsera.org/index.php/parahita/article/view/270/523, diakses 12 Januari 2018).

Sudjana, N. (2008). Dasar-dasar Evaluasi Pembelajaran. Jakarta: Rineka Cipta

Suherman, E. (2008). Belajar dan Pembelajaran Matematika. Hand-Out Perkuliahan Jurusan Pendidikan Matematika FPMIPA UPI: tidak diterbitkan.

Sugiyono. (2010). Metode Penelitian Pendidikan. Bandung: Alfabeta. Sukmadinata, N. (2008). Metode Penelitian Pendidikan. Bandung: Rosda.

Supriani, Y. dan Oktaviyanthi, R. (2014). The Influence of Compact Disk Interactive Learning Model and Student's Creativity Toward the Understanding of Mathematics Concepts. International Journal of Education and Research, 2 (7), 535-540. (Online), (https://pdfs.semanticscholar.org/cee1/6135957251054ceb0e686eb0bf5d31f cc0fa.pdf, diakses 11 September 2017).

Susanti, N.I. dkk. (2015). Analisis Kesulitan Siswa Dalam Pemahaman Materi Fungsi Komposisi Siswa Kelas XI Semester 2 MAN Pesanggaran. Jurnal Nasional Pancaran Universiatas Jember. (Online), (https://jurnal.unej.ac.id/index.php/pancaran/article/view/2182, diakses 13 Agustus 2016).

Uno, H.B. dan Umar, M.K. (2009). Mengelola Kecerdasan Dalam Pembelajaran Sebuah Konsep Pembelajaran Berbasis Kecerdasan. Jakarta: PT Bumi Askara. 